\title{
Covid-19 pandemisi sırasında yaşlı kalça kırıklarına yaklaşım
}

\author{
Approach to elderly hip fractures during the Covid-19 pandemic
}

\author{
Mehmet Mesut Sönmez
}

SBÜ Hamidiye Etfal Eğitim Araştırma Hastanesi, Ortopedi ve Travmatoloji Kliniği, İstanbul

\begin{abstract}
31 Aralık 2019 tarihinde, Çin'in Hubei eyaletinin Vuhan şehrinde sebebi o an için bilinmeyen pnömoni olgularının Dünya Sağlık Örgütü Çin Ülke Ofisi tarafından bildirilmesi ve etkenin 5 Ocak 2020 tarihinde daha önce insanlarda tespit edilmemiş yeni bir koronavirüs tanımlanması ile Covid-19 pandemisinin başlangıç noktası kabul edilebilir. Üç ay gibi kısa bir süre içerisinde tüm dünyayı etkisi altına alması üzerine 12 Mart 2020 itibariyle Dünya Sağıı Örgütü tarafından pandemi olarak ilan edilen Covid-19 salgını; fiziksel, ruhsal ve sosyal olarak dünya insanlığını tehdit etmeye devam etmektedir. Salgının boyutu her branşta olduğu gibi ortopedi ve travmatoloji alanında da tedavi ve hastaya yaklaşım protokollerinde ciddi değişikliklere neden olmuştur. Ulusal boyutta sağlık hizmetlerinin yürütülmesi için çeşitli önlemler alınmıştır. Özellikle Covid-19 açısından yüksek risk altında olan ve azımsanamayacak oranda tedavi edilen yaşlı kalça kırıklarının yönetimi açısından da yeni yaklaşımların ortaya çıkarılması kaçınılmaz olmuştur.
\end{abstract}

Anahtar sözcükler: kalça kırı̆ı̆; Covid-19; pandemi

\begin{abstract}
The starting point for the Covid-19 pandemic can be considered with the notification of cases of pneumonia, whose cause is unknown at the time, by the World Health Organization's China Country Office on December 31, 2019. The identification of a new coronavirus that has not previously been detected in humans on January 5, 2020. The Covid-19 outbreak, declared pandemic by the World Health Organization as of March 12, 2020, because of taken its place all over the world in as little as three months. Covid-19 pandemic still continues to threaten physically, spiritually and socially whole of the world and its human beings. The scale of the outbreak has caused significant changes in treatment and patient approach protocols in the field of orthopedics and traumatology as well as in all branches. Various measures have been taken to conduct health services on a national scale. It has also been inevitable that new approaches will be revealed, especially in terms of the management of elderly hip fractures, which are at high risk for Covid-19.
\end{abstract}

Key words: hip fracture; Covid-19; pandemic ovid-19 pandemisi; başlangıçta yeni bir CoV (novel CoV (2019-nCoV)), sonrasında şiddetli akut solunum yolu sendromuna (SARS, Severe Acute Respiratory Syndrome) neden olması nedeniyle SARSCov-2 olarak adlandırılan hayvanlarda saptanan bir koronavirüs alt türü nedeniyle ortaya çıkmıştır. İnsanlarda çoğunlukla soğuk algınlığı gibi hafif şikâyetler ile seyreden hastalığa neden olan alt tiplerin (HCoV-229E, HCoVOC43, HCoV-NL63 ve HKU1-CoV) aksine SARS-Cov-2 dünya genelinde sağlık sistemlerini oldukça güç duruma düşüren pandemi tablosuna neden olmuş̧tur. ${ }^{[1,2]}$

Dünya Sağlık Örgütü (DSÖ)'nün Çin Halk Cumhuriyeti Ofisi, ilk olarak 31 Aralık 2019 tarihinde, Çin'in Hubei eyaletinin Vuhan şehrinde bildirilen ve etiyolojisinin saptanamadığı pnömoni olgularını duyurmuştur.
30 Ocak 2020'de DSÖ, tarafından Covid-19 salgını "Uluslararası Boyutta Halk Sağlığı Acil Durumu" olarak tanımlanmış; salgının çıkış noktası olan Çin Halk Cumhuriyeti dışında toplam 113 ülkede olguların bildirilmesi, virüsün yayılımı ve ölümcül sonuçları sebebiyle 11 Mart 2020'de küresel salgın (pandemi) olarak tanımlamıştır. Bugüne kadar dünyada Antarktika dışındaki tüm kıtalarda teyit edilmiştir. ${ }^{[3]}$ Ülkemizde ise doğrulanmış ilk olgu 11 Mart 2020'de bildirilmiştir. 19 Eylül 2020 tarihi itibarı ile dünyada 30.369 .778 doğrulanmış olgu, 948.795 ölüm; Türkiye'de ise 299.810 olgu, 7.377 ölüm bildirilmiştir. ${ }^{[4]}$

Gerek toplum kaynaklı gerekse sağlık hizmeti sunumu esnasında enfeksiyon zincirinin ve bulaşma özelliklerinin bilinmesi hayati önem taşır.

- Illetişim adresi: Doç. Dr. Mehmet Mesut Sönmez, SBÜ Hamidiye Etfal Eğitim Araştırma Hastanesi, Ortopedi ve Travmatoloji Kliniği, Halaskargazi Cd., 34371 Şişli, İstanbul Tel: 0532 - 3341155 e-posta: mdmesutsonmez@yahoo.com 
Enfeksiyon zinciri; kaynak, bulaş yolu ve konakçıdan meydana gelir. Kabul edilen görüş SARS-CoV-2'nin kaynağının satılan vahşi hayvanlar olduğu yönündedir. Sonrasında olası geçirilmiş mutasyon sonrası insandan insana bulaş özelliği kazandığı böylelikle, kaynak semptomatik ve asemptomatik COVID-19 pozitif insanlar olarak değişmiştir. ${ }^{[3]}$

Bulaş yolunun solunum damlacıkları olduğu yönünde yaygın görüş birliği vardır. Öksürük, hapşırık ve konuşma esnasında damlacık yolu ile saçılan virüs, enfekte yüzeylere dokunma sonrası virüs burun ağız mukozası ve göz ile teması sonrası mukozalara tutunarak hastalık bulaşmayı tamamlar. Damlacıkların 2 metreden daha uzağa ulaşamadığı ve havada uzun süre asılı kalmadığı bilinmektedir. ${ }^{[5]}$

Covid-19 dış ortama, alkol ve dezenfektanlara dayanıksız olup yüzeylerde 24 ila 72 saat canlı kalabilmektedir (karton, plastik ve çelik yüzeyler). Virüsün RNA'sı şikayetlerin başlamasından 5 gün sonra kan, idrarve tükürükte izole edilebilmiş ve bu 4-5'inci haftalara kadar izole edilmesi devam edilebilmektedir. Nazofarengeal sürüntüde ve dışkıda bir aydan uzun süre izole edilen olgular mevcuttur. DSÖ-Çin ortak raporuna göre, kan ve dışkıda izole edilse de feko-oral yol bulaş yolu olarak kabul edilmemektedir. Hava yolu ile bulaşıp bulaşmayacağı tartışmalı bir konudur. COVID-19 hastalarının yattığı hastane odalarından alınan hava örneklerinde ve havalandırma sistemlerinde viral RNA saptanmış, canlı virüs kültürlerde izole edilememiştir. Solunum yolu virüsleri genellikle kan yoluyla bulaşmazlar. SARSCoV-2 enfeksiyonu için de bugüne kadar transfüzyonla bulaş bildirilmemiştir. ${ }^{[6,7]}$

Enfeksiyon zinciri açısından diğer önemli bir faktör bulaş süresidir. Bulaş süresi hala belirsizdir. Semptomların ortaya çıkmasından önce ve hastalık boyunca bulaşıcı olduğu bilinmektedir. Bulaştırıcılık süresi henüz net olarak bilinmemektedir. Bulaşıcılığın semptomların başlamasından 1-2 gün önce başlayıp (2-14 gün) semptomların kaybolmasıyla bittiği düşünülmektedir. Nasofarengeal sürüntüde viral RNA saptamasının mutlak bulaşıcılığa neden olmadığı bildirilmiştir. ${ }^{[8-11]}$ COVID-19 hastalarının, hastane odalarında yoğun SARS-CoV-2 kontaminasyonu tanımlanmıştır. Benzer çalışmalarda yüzey dezenfektanlarının (\%62-71 konsantrasyonlarda etanol dâhil), 1 dakika içinde SARS-CoV-2 dâhil birçok virüsü inaktive ettiği gösterilmiştir. ${ }^{[12]}$

Konak olarak insanların \%80'i tıbbi müdahaleye gereksinim duymadan hastalığı geçirir. Ciddi olgularda pnömoni ve solunum desteği ortaya çıkmaktadır. Hipertansiyon, diyabet, akciğer ve kalp hastalıkları gibi kronik rahatsızlıkları bulunan bireylerde ve yaşlı nüfusta hastalık ciddi seyretmektedir. Kuluçka süresi sonrası ilk başlayan bulgular yüksek ateş, öksürük ve nefes darlığıdır. Bazı hastalarda bu tabloya boğaz ağrısı ve burun akıntısı da eşlik etmektedir. Orta klinik seyir gösteren olgularda tıbbi destek ile yönetilebilmekte, ağır olgularda; pnömoni, septik şok, akut respiratuvar distres sendromu (ARDS) ve çoklu organ yetmezliği hastalığın komplikasyonları olarak görülebilmektedir, bu tablo genellikle ölümle sonuçlanmaktadır ${ }^{[1]}$.

Yaşlı kalça kırıkları (>65 yaş) osteoporotik kırıkların yarısından fazlasını oluşturmaktadır. 2050 yılı itibari ile dünya genelinde yaklaşık 6,3 milyon yaşı kalça kırığı olgusu beklenmektedir. ${ }^{[13]}$ Mortalite ve morbidite oranları oldukça yüksektir. Illk ay ölüm oranları \%3,5 ila \%10 arasında bildirilmiştir. Bu oran giderek azalır. ${ }^{[14]}$ Yaşlı popülasyonda Covid-19 enfeksiyonun ağır seyretmesi ve sıklıkla ölümle sonuçlanması nedeniyle kalça kırıklarının yönetimi kırıkların kendi başına yüksek mortalitesi ile birleşince önem kazanmaktadır. Literatürde Covid-19'lu kalça kırıklarının prognozu ile ilgili sınırlı sayıda yayın mevcuttur. Beklendiği gibi Covid-19'lu yaşlı kalça kırıklarında ilk 30 gün ölüm oranları yüksektir. ${ }^{[15-17]}$

Şüphesiz yaşlı kalça kırıklarının yönetiminde ana rol ortopedi ve travmatoloji uzmanlarındadır. Ancak pandemi döneminde ülke genelinde tedbirler alınması ve ortopedi ve travmatoloji ile diğer branşlarda sağlık hizmetlerinin sunumu ile ilgili normalden farklı koruyucu ve hasta yönetimi yaklaşımlarının planlanması kaçınılmazdır.10 Ocak 2020 tarihinde Sağlık Bakanlığı koordinesinde kurulan Koronavirüs Bilim Kurulu ve Operasyon Merkezi'nin önerileri ile ortopedi ve travmatoloji alanını da ilgilendiren yönetimsel anlamda birçok tedbir uygulamaya girmiştir.11 Mart 2020'de ilk olgunun resmi olarak bildirilmesi ile sırasıly; ilk, orta dereceli okullar ve üniversitelerde eğitime ara verilmesi, ibadethanelerde toplu ibadetlerin yasaklanması, 65 yaş üstü ve kronik hastalığı olanlara sokağa çıkma yasağı sınırı getirilmesi ve "Hayat eve sı̆̆ar" kampanyası ile evden çıkması gerekmeyen kişilerin evde kalması ve evden çalışma yönünde öneriler ve esnek çalışma saatleri uygulamasına gidildi. Bu tedbirler özellikle ev dışı orta ve yüksek enerjili travma sonrası meydana gelen kalça kırıklarının meydana gelmesinde azalmaya neden olmuştur.

Yaşlı kalça kırıklarının etiyolojisinde özellikle ev içi basit düşmeler gelmektedir. Yalnız ve/veya yaşlı eşleri ile yaşayan ve ev içi tüm ihtiyaçlarını kendi başlarına gideren bu popülasyon grubunda ihtiyaçlarını giderirken ev içi basit düşmelerin olması bilinen bir gerçektir. Pandemi önlemleri çerçevesinde genç nüfusun yaşlıları koruma amacıyla uzak kalmaları ve yaşılırın riske daha fazla maruz kalması beklenir ancak bu konu ile ilgili bilimsel bir çalışma henüz yoktur. 


\section{YENI NORMALLEŞME DÖNEMI ÖNCESI YAKLAŞIM}

Ülkemizde 20 Mart 2020 tarihinde kadrosunda; enfeksiyon hastalıkları ve klinik mikrobiyoloji, gögüus hastalıkları, iç hastalıkları uzmanı hekimlerinden en az ikisinin bulunduran ve üçüncü basamak erişkin yoğun bakım yatağı bulunan hastaneler, Sağlık Bakanlığı tarafından, "pandemi hastaneleri" olarak kabul edildi. $\mathrm{Bu}$ hastanelerin Covid-19 tanısı konulmuş olguların tedavisinde yer alması sağlandı. İstanbul özelinde bu tarih itibari ile hastanelerin rol modellerinde kaçınılmaz değişiklikler zorunlu hale geldi. Özellikle Avrupa yakasında tüm yan dal dışı eğitim araştırma hastaneleri yeni normalleşme döneminin başlangıcı olan Haziran 2020 tarihine kadar yatak kapasitelerinin hemen hepsini Covid-19 olgu yönetimine ayırmış, diğer branşlarda başvuran hastaların tedavisi yan dal eğitim ve araştırma hastanelerinde yürütülmüştür. Elektif olguların kamu hastanelerinde sınırlandırılması ve ertelenmesi kararı özellikle Covid-19 olguların yönetilmesi aşamasında kolaylık sağlamıştır. Yoğun bakım ünitelerinin yönetiminde ana rolü üstlenen anestezi ve reanimasyon uzmanlarının elektif cerrahi olgularında görev almaması pandemi yönetimi açısından yarar sağlamıştır.

İstanbul ili özelinde yeni normalleşme döneminin başlangıcı olan Haziran 2020 tarihine kadar yaşlı kalça kırıklarının tedavisinde "pandemi hastanesi" rolünü üstlenmiş eğitim araştırma hastaneleri hemen hiç görev almamıştır. Bu hastaların tedavilerinin yönetiminde yan dal eğitim araştırma hastanesi ana rolü üstlenmiştir. Hastaların nakil işlemleri başvurdukları pandemi hastanelerinden ivedi olarak sağlanmış ve hastaların pandemi hastanelerinde virüse maruz kalmaları en aza indirilmeye çalışılmıştır. Diğer yandan branş hastanelerinde sunulan sağlık hizmeti sunulmasında karşılaşılan zorlukların başında bu hastanelerde ihtiyaç halinde diğer uzmanlaşmış branş hekimlerinin bulunmaması ve özellikli birimlerin yer almaması sayılabilir. Özellikle ek hastalık ve riskli grupta yer alan yaşlı kalça kırıklı hastalar için; yoğun bakım, diyaliz girişimsel kardiyolojik ve diğer işlemlerin branş hastanelerince karşılanmasında güçlükler yaşanması beklenir.

Sonuç olarak pandemi dönemi ve önlemlerinin yaşIı kalça kırıklarının etiyolojisine yönelik orta ve yüksek enerjili travma nedenlerini azalttığı ev içi düşme nedenine yönelik olumlu ve olumsuz etkileri olduğu söylenebilir. İstanbul ili özelinde yaşlı kalça kırıklı hastaların yönetiminde kamu yan dal eğitim araştırma hastanesi öncülüğünde yürütülmüş diğer hastanelerin kapasiteleri Covid-19 olguların yönetimi için kullanılmıştır.

\section{YENI NORMALLEŞME DÖNEMi}

COVID-19 olgularında düşüş eğiliminin belirtileri ile 1 Haziran 2020 tarihi itibari ülkemizde her alanda olduğu gibi sağlık alanında da yeni normalleşme sürecinde sağlık hizmetinin sunumu ile ilgili öneriler ve tedbirler Sağlık Bakanlığı koordinesinde kurulan Koronavirüs Bilim Kurulu ve Operasyon Merkezi tarafindan ortaya konuldu. ${ }^{[18]}$ Ortopedi ve travmatoloji branş derneği ile birlikte birçok branş derneği de bu yeni normalleşme dönemi ile ilgili önerilerini içeren rehberleri hekimlere sunmuştur. ${ }^{[19,20]}$

\section{Yaşlı Kalça Kırıklarında Ortopedi ve Travmatoloji Kliniklerindeki Hekimlerin Davranışları}

Eğitim, pandemi döneminde sağlık çalışanlarının kendilerini korumak ve sağlık hizmetlerinin aksamadan yürütülmesini sağlamakta temel oluşturur. Covid-19 pandemisi özelinde eğitimlerin güncellenerek sürdürülmesi önemlidir. Hastane idarelerinden bu konu ile ilgili destek talep edilmeli ve eğitimler kayıt altına alınmalıdır. Çalışanlara gerekli kişisel koruyucu ekipman (KKE) temin edilmeli ve doğru kullanım sağlanmalıdır.

Acil servise başvuran yaşlı kalça kırıkları Covid-19 bulguları açısından sorgulanmalıdır. Hasta ve refakatçisinin maskeli olması en önemli korunma önlemlerinin başında gelir. Temassız ateş ölçümü, öksürük, boğaz ağrısı ve nefes darlığı gibi bulguların sorgulanması Covid-19 tanısı açısından önem taşır. Hastanın ve temasta bulunduğu kişilerin bulgular açısından sorgulanması önemlidir.

\section{Covid-19 Pandemisinde Yaşlı Kalça Kırıklarının Yönetimi}

Hastaların değerlendirilmesi yukarıda belirtilen şartlar ve sorgular ile başlanmalı, hastanın yanında bulunan refakatçi sayısı en azda tutulmalıdır. Özellikle başvuru alanı olan acil servislerde hastanın gerekenden fazla zaman geçirmesinden kaçınılmalıdır. Tekrarlayan filmler vs. gibi hastane içinde yatıştan önce hastanın gereksiz yere fazla zaman geçirmesinden kaçınılmalıdır. Yatış öncesi kalça kırığı ile ilgili onamlar ile birlikte Covid-19 özelinde onamların alınması medikolegal açıdan önem taşımaktadır. Servise alınan hastanın mümkün olan durumlarda tekli odada, birden fazla hastanın bulunması durumunda ise odadaki her hastanın ve refakatçinin maske, mesafe ve hijyen kurallarına uyduğundan emin olunmalıdır. Hastaya refakat eden kişinin aynı olmasına ve hastanedeki yatış sürecinde dış ortamla temas etmemesine ve refakatçinin değişmemesine dikkat edilmelidir. 


\section{Ameliyat öncesi hazırlık}

Covid-19 pandemisi, ameliyat öncesi değerlendirme protokollerine ek protokollerin işlenmesini zorunlu kılmıştır. Her ne kadar açık kırıklar, damar yaralanmaları ve septik artrit gibi ortopedi ve travmatoloji alanındaki aciller arasında yer almasa da yaşlı kalça kırıkları ameliyat öncesi hazırlık sonrası erken dönem tedavi edilmesi gereken kırıklardır. Bu, özellikle yatağa bağı pnömoni gibi komplikasyonların gelişiminin önlenmesinde rol oynar. 24 saatten önce ameliyat edilen yaşlı kalça kırıklarında ilk 30 günde ölüm oranlarının düştüğünü bildiren yayınlar mevcuttur. ${ }^{[21]}$ Acil başvuru esnasında başlanan semptomlar açısından sorgulanma her gün tekrarlanmalı, koşulların sağlanması durumunda hastanın burun ve boğaz sürüntüsünden RT-PCR (Reverse transcription polymerase chain reaction) testi uygulanmalıdır. Asemptomatik hastalarda rutin Toraks BT (bilgisayarlı tomografi) önerilmemektedir.

\section{Hastanın ameliyathaneye transferi öncesi hazırlıklar}

Alışılagelmişin dışında Covid-19 pandemi döneminde ameliyathane odalarının negatif basınçlı olarak ayarlanması önerilmektedir. Cerrahi için gerekli olabilecek tüm malzemelerin önceden hazır bulundurulması odaya fazladan giriş ve çıkışları en aza indirgemektedir. Tüm ekip için KKE uygun şekilde hazır olduğundan emin olunmalıdır. Cerrahi öncesi odanın yeterince temizlendiğinden emin olunmalıdır. Temizlik için ayrılacak süre odanın hava değişimini de yeterince sağlayacaktır.

\section{Hastanın ameliyathaneye transferi}

Hastanın maske ile transferinin sağlanması esastır. Hasta ameliyat öncesi hazırlık alanına alınmadan doğrudan ameliyathane salonuna alınmalıdır.

\section{Anestezi uygulamaları}

Anestezi öncesi ve anestezi esnasında odanın ihtiyaç dışı personelden arındırılması esastır. Mümkün olduğunca aerosol oluşumuna neden genel anestezi prosedürlerinden kaçınılmalı ve spinal anestezi tercih edilmelidir.

\section{Ameliyat teknikleri}

Cerrahi ekip sayısı optimum düzeyde tutulmalıdır. Koter kullanımı en aza indirilmelidir. Duman aspirasyonu önem arz etmektedir. Aerosol üretimine neden olan oyucu ve kesicilerin kullanımına dikkat edilmeli, siperlik kullanımı sağlanmalıdır. ${ }^{[22]}$ Seçilen ameliyat tekniği veya implantlardan bağımsız olarak yaşlı kalça kırıklarının prognozunu iyileştirmede ameliyat süresinin kısa olması, yumuşak doku hasarının ve kan kaybının en aza indirilmesi esastır.

\section{Cerrahi sonrası bakım}

Ameliyat sonrası hastada ateş olması halinde ateş nedeninin Covid-19 enfeksiyonu veya cerrahi alan kaynaklı olup olmadığının ayııımı büyük önem taşır. Enfeksiyon belirteçlerinin (hemogram, beyaz küre sayısı, nötrofil sayımı, lenfosit sayımı, c-reaktif protein ve prokalsitonin değerleri) değerlendirilmesi, cerrahi alanda akıntı ve Covid-19'a özgü radyolojik değerlendirmenin yapılması önemlidir. Cerrahi sonrası ortaya çıkan solunum güçlüguü ve düşen kan oksijen saturasyon değerlerinin pulmoner emboli ve Covid-19 enfeksiyon ayırıcı tanısı açısından önem taşır.

Olası veya kesinleşmiş tanısı olan yaşlı kalça kırıklı hastaların cerrahi sonrası enfeksiyon hastalıkları ve/ veya göğüs hastalıkları uzmanları ile birlikte yakın takibi zorunlu hale gelir.

Ameliyat olan yaşlı kalça kırıklarının hızlıca rehabilite edilmesi ve mümkün olan en kısa sürede hastaneden taburcu edilmesi esastır. Erken rehabilitasyon bası yarası ve akciğer problemleri gibi komplikasyonları azalttığı gibi, erken taburculuk sayesinde hastane kaynaklı Covid-19 bulaşmalarının da önüne geçilmesini sağlar.

\section{Covid-19 Pandemisinde Yaşlı Kalça Kırıklarına Neden Daha Dikkatli Yaklaşılmalıdır?}

Covid-19'un yaşlı hastalarda prognozu oldukça kötü seyretmektedir. Genç hastalara göre altta yatan kalp yetmezliği, hipertansiyon vb. hastalıklar nedeni ile yaşlılarda ölüm oranları oldukça yüksektir.[${ }^{[23]}$ Yatağa bağımlı olma nedeni ile ortaya çıkan akciğerlere ait komplikasyonların başında staz pnömonileri gelmektedir. Hastaneye yatıştan kısa bir süre sonra ortaya çıkabilen bu durum Covid-19 pnömonileri ile kolaylıkla karıştırılabilir.

Covid-19 enfeksiyonunun eşlik ettiği yaşlı kalça kırıklarında ilk 30 günlük mortalitenin \%50'lilere vardığını bildiren yayınlar mevcuttur. Travma sonrası cerrahi yaşlı hastalarda ikinci darbe olarak adlandırılabilir. Bu, hastanın enflamatuvar cevaba ve sonuçlarına maruz kalmasına neden olur. Covid-19'un sebep olduğu sitokin fırtınası bu hastalarda üçüncü ve ölümcül enflamatuvar darbe olarak tanımlanabilir. ${ }^{[17]}$ Toplum kaynaklı bulaş olan kalça kırıklarının yatış anında tespit edilmesi hastanın prognozuna etkileri olduğu gibi ortopedi ve travmatoloji hizmetini sunanların kendilerini korumaları açısından kritik öneme sahiptir. Ayrıca hastane kaynaklı Covid-19 bulaşmalarının önlenmesinde ortopedi ve travmatoloji uzmanlarına büyük görev düşmektedir. Yukarıda sıralı önlemlerin alınması, eğitim ve rehberlerin eşliğinde hareket etmek bu konuda bize büyük katkı sağlayacaktır. 
Ortopedi ve travmatoloji uzmanları özellikle acil hizmetlerde en önde yer alan sağıık hizmeti sunucularıdır. Yaşlı kalça kırıklarında olduğu gibi travma hastalarına ilk müdahale eden sağlık ekibi içinde yer alırlar. Hasta seçimi veya hastanın tıbbi durumunu göz ardı etme gibi seçme şansları yoktur. Sadece Covid-19'da değil, kan yolu ile bulaşabilen birçok bulaşıı hastalıkta risk altındadırlar. Bu nedenle tedbir ve önlemler eşliğinde hareket etmek hayati önem arz etmektedir.

\section{KAYNAKLAR}

1. Huang $C$, Wang $Y$, Li $X$, Ren L, Zhao J, Hu Y, Zhang L, Fan G, Xu J, Gu X, Cheng Z, Yu T, Xia J, Wei Y, Wu W, Xie X, Yin W, Li H, Liu M, Xiao Y, Gao H, Guo L, Xie J, Wang G, Jiang R, Gao Z, Jin Q, Wang J, Cao B. Clinical features of patients infected with 2019 novel coronavirus in Wuhan, China. Lancet 2020;395(10223):497-506. Crossref

2. Channappanavar R, Perlman S. Pathogenic human coronavirus infections: causes and consequences of cytokine storm and immunopathology. Semin Immunopathol 2017;39(5):529-39. Crossref

3. Şirin H, Özkan S. COVID-19 Epidemiology: In the World and Turkey. J Ear Nose Throat Head Neck Surg 2020;28(Suppl):S6-13. Crossref

4. World Health Organization (WHO). Global. https://www. who.int/

5. Wu D, Wu T, Liu Q, Yang Z. The SARS-CoV-2 outbreak: What we know. Int J Infect Dis 2020;94:44-8. Crossref

6. Ong SWX, Tan YK, Chia PY, Lee TH, Ng OT, Wong MSY, Marimuthu K. Air, Surface Environmental, and Personal Protective Equipment Contamination by Severe Acute Respiratory Syndrome Coronavirus 2 (SARS-CoV-2) From a Symptomatic Patient. JAMA 2020;323(16):1610-2. Crossref

7. Guo ZD, Wang ZY, Zhang SF, Li X, Li L, Li C, Cui Y, Fu RB, Dong YZ, Chi XY, Zhang MY, Liu K, Cao C, Liu B, Zhang K, Gao YW, Lu B, Chen W. Aerosol and Surface Distribution of Severe Acute Respiratory Syndrome Coronavirus 2 in Hospital Wards, Wuhan, China 2020. Emerg Infect Dis 2020;26(7):1583-91. Crossref

8. Liu $Y$, Ning Z, Chen Y, Guo M, Liu Y, Gali NK, Sun L, Duan Y, Cai J, Westerdahl D, Liu X, Xu K, Ho KF, Kan H, Fu Q, Lan K. Aerodynamic analysis of SARS-CoV-2 in two Wuhan hospitals. Nature 2020;582(7813):557-60. Crossref

9. Zou L, Ruan F, Huang M, Liang L, Huang $H$, Hong Z, Yu J, Kang M, Song Y, Xia J, Guo Q, Song T, He J, Yen HL, Peiris M, Wu J. SARS-CoV-2 Viral Load in Upper Respiratory Specimens of Infected Patients. N Engl J Med 2020;382(12):1177-9. Crossref

10. Pan Y, Zhang D, Yang P, Poon LLM, Wang Q. Viral load of SARS-CoV-2 in clinical samples. Lancet Infect Dis 2020;20(4):411-2. Crossref

11. Lauer SA, Grantz KH, Bi Q, Jones FK, Zheng Q, Meredith HR, Azman AS, Reich NG, Lessler J. The Incubation Period of Coronavirus Disease 2019 (COVID-19) From Publicly Reported Confirmed Cases: Estimation and Application. Ann Intern Med 2020;172(9):577-82. Crossref
12. Kampf G, Todt D, Pfaender S, Steinmann E. Persistence of coronaviruses on inanimate surfaces and their inactivation with biocidal agents. J Hosp Infect 2020;104(3):246-51. Crossref

13. Parker M, Johansen A. Hip fracture. BMJ 2006;333(7557):2730. Crossref

14. Daugaard CL, Jørgensen HL, Riis T, Lauritzen JB, Duus BR, van der Mark S. Is mortality after hip fracture associated with surgical delay or admission during weekends and public holidays? A retrospective study of 38,020 patients. Acta Orthop 2012;83(6):609-13. Crossref

15. Catellani F, Coscione A, D'Ambrosi R, Usai L, Roscitano C, Fiorentino G. Treatment of Proximal Femoral Fragility Fractures in Patients with COVID-19 During the SARSCoV-2 Outbreak in Northern Italy. J Bone Joint Surg Am 2020;102(12):e58. Crossref

16. Egol KA, Konda SR, Bird ML, Dedhia N, Landes EK, Ranson RA, Solasz SJ, Aggarwal VK, Bosco JA 3rd, Furgiuele DL, Ganta A, Gould J, Lyon TR, McLaurin TM, Tejwani NC, Zuckerman JD, Leucht P; NYU COVID Hip Fracture Research Group. Increased Mortality and Major Complications in Hip Fracture Care During the COVID-19 Pandemic: A New York City Perspective. J Orthop Trauma 2020;34(8):395-402. Crossref

17. Fadulelmola A, Gregory R, Gordon G, Smith F, Jennings A. The impact of COVID-19 infection on hip fractures 30-day mortality. Trauma 2020:1460408620951352. Crossref

18. T.C. Sağıık Bakanlığı. Covid-19 Bilgilendirme Sayfası. Covid-19 Rehberi. Güncellenme Tarihi: 03 Eylül 2020. https://covid19. saglik.gov.tr/TR-66301/covid-19-rehberi.html

19. Türk Ortopedi ve Travmatoloji Birliği Derneği (TOTBID). Covid-19: Elektif Cerrahiye Dönüşte Totbid Görüşü. $\quad$ http://www.totbid.org.tr/totbid/haber/ covid-19--elektif-cerrahiye-donuste-totbid-gorusu/20661

20. Sungur Z, editör. Anesteziyoloji ve Reanimasyon Uzmanları İçin Covid-19 Pandemisi Normalleşme Döneminde Elektif Cerrahilere Başlama Önerileri (1. Edisyon). İstanbul Üniversitesi İstanbul Tıp Fakültesi, 21 Mayıs 2020. https:// services.hippocrapp.com/HippocrappServiceV2/files/static/ medicalData/lke7wga1fagms2v1n0mt.pdf

21. Pincus D, Ravi B, Wasserstein D, Huang A, Paterson JM, Nathens AB, Kreder HJ, Jenkinson RJ, Wodchis WP. Association Between Wait Time and 30-Day Mortality in Adults Undergoing Hip Fracture Surgery. JAMA 2017;318(20):1994-2003. Crossref

22. van Doremalen $\mathrm{N}$, Bushmaker $\mathrm{T}$, Morris $\mathrm{DH}$, Holbrook MG, Gamble A, Williamson BN, Tamin A, Harcourt JL, Thornburg NJ, Gerber SI, Lloyd-Smith JO, de Wit E, Munster VJ. Aerosol and Surface Stability of SARS-CoV-2 as Compared with SARS-CoV-1. N Engl J Med 2020;382:1564-7. Crossref

23. Liu K, Chen Y, Lin R, Han K. Clinical features of COVID-19 in elderly patients: A comparison with young and middle-aged patients. J Infect 2020;80(6):e14-8. Crossref 